\title{
The Biblical Mythological Images of American Women in the Novel of Mice and Men
}

\author{
Gibran Banhakeia \\ Pluridisciplinary Faculty of Nador \\ gbanhakeia@yahoo.com
}

\begin{abstract}
This research aims at deconstructing the essential images of women during the period of Puritans that resided in the deeply mythologized text of John Steinbeck (Of Mice and Men) and this paper is about to analyze as to how biblical texts are paradigms of inferiority, inasmuch as sacred texts define women as bodies of sexuality. Henceforth, this research can elucidate the vague side of women in comparison with the religious minitexts in "Of mice and Men". We can analyze Steinbeck's inspiration from the Bible from in order to understand his personal feedback on women that means we are on the verge of analyzing the social position of women that lived harshly during the momentum of Great Depression in the American Literature.
\end{abstract}

Keywords: Women, Steinbeck, Images, Sexuality, Bible

\section{INTRODUCTION}

The History of American literature retells to its universal public that there are positive and clashing conclusions about the unsaid realities of women that cannot be retold again through the eyes of feminist writers who skipped admitting how religion plays a dangerous role of exploiting women. The vague image of woman lets us today to scrutinize how religion mythologizes his biblical consciousness of John Steinbeck even if he paradoxically defends the status of women that we clearly deconstruct through this writings. Hence, this research would focus on the unvoiced issues of culture regarding women social situations through John Steinbeck's novel "Of Mice and Men" in the light of portraying the status of an ordinary American Woman that is symbolically exploited and badly described and paradoxically defended by religious texts. Therefore, it is a must to analyze literary, political and religious conflicts that shape the world of Steinbeck, because, in that, we can claim that the world of Hollywoodean Stars is something far away from the reality of (rural) Californians. The inaccurate image of sexuality on females is still existed in United States despite the role Postmodernism plays such farreaching advances in revising mistakes of the puritans. Nevertheless, this study will not deconstruct the image of women's today, inasmuch as we vehemently attempt to shed more light on how writers of the Twentieth century - John Steinbeck - define religiously and defend socially women through his artistic descriptions that put him in the situation of being as a paradoxical author.

It is effectively true that this research is bound to explore biblical tracks and social trails that structure the main part of conveying how negative feedbacks on women are predominantly registered in Americans collective consciousness. Secondly, The clashing moments of women should be analyzed by looking at the historical and social images of their lives to contextualize "The Bible" primarily as the inspiration of the author in the hope of showing how religious group (Puritanism ) is the mainstream ideology of developing American [national] literature and deteriorating it at the same moment, nonetheless this period, doesn't only develop literature, but it truly depicted women mentally to be defined only as "Bodies of Sexuality": This spot would direct us to scrutinize two focal ideas: John Steinbeck is unconsciously dominated by the realm of religious ideology that is the reason of his sacred description "Sexual Creatures". But, he paradoxically defends them socially. In a nutshell, Considering John Steinbeck as the novelist means a positive image regarding the women's rights; 
The Biblical Mythological Images of American Women in the Novel of Mice and Men

unlike, looking at John Steinbeck from the novel's [Of Mice and Men] deep structure as the author, not the writer, would puzzle the reader to understand that he favors more and more the paradigm of religion rather than defending women socially. In fact, this inquiry is paradoxically as the main problematic statement, albeit it contains two essential objectives:

1- To demonstrate John Steinbeck uses the religious symbols when he describes women to convey them as bodies of sexuality

2- To clearly explain how he defends women, paradoxically.

It is granted studying religious mythology in John Steinbeck's novel - Of Mice and Men, is not such an easy to task to being with, but mythocriticism would be as the essential tool to analyze the gap of collective consciousness of Steinbeck.

\section{RESEARCH QUESTIONS}

1. Why does Steinbeck portray Leenie as someone who hates Women?

2. Why does Steinbeck describe the negative side of women through religious texts?

3. Why does he defend them socially?

\section{METHOD}

This text takes form of an eclectic strategy seeing that we are about to scrutinize different elements of American history based upon mythocritical analysis in such a way to grasp the dazzling gap of religious images that define woman as "the corpse". This method depends evidently on our analysis to see how the author is negatively and positively depicted the position of women.

\section{The Image of Women Through the Eyes of American PuRitans}

In view of the potential Image of religious texts in Modern American literature, writers like John Steinbeck are clearly influenced by the domination of Puritanism even this quality is not mentioned in his biographical events, but it is a noticeable image of the most American authors of the twentieth century. The era of puritanism is revealed as the momentum of suffering that put females into difficult situations of exploitation. In fact, reading what Peter B. High says about this movement in his book of "Introduction to American Literature" is extremely fearful (High, Peter B : 1986):

"Unlike the Puritans who saw man as a sinful failure" 1

The first religious settlers in American are "Puritans" as well they were not democratic people due to the radical texts forcefully colonized mentally their thoughts. Whenever and wherever they find men or women who do not obey the rules of god, they are considered as the followers of Satan. Everybody has to be presented at the Church, if something goes wrong inside the church, thereby they have to find the main cause of her unknown curse by fetching the houses of ordinary people till they find the so-called "the female witch"; those who stay a home and do not go daily to the house of god "The Church" should be called "Snakes". To say it differently, this period is characterized by the rules of theocracy, which means the laws of society and the laws of religion are equals (Ibid).

The role of woman in American society is such a vague question that demands myriads of historical researches in the light of providing such convincing results that explain some negative images of women that were dominated by puritanism. After a long period of harshness and abduction; after many years of considering women as witches, even witchcraft was a poorly way of earning money because of poverty and whenever women chose to change their religious rules or to forget assisting at the church, they have been instantly considered as the dangerous [black] witches; then, they are immediately perceived against the faith of god, because Puritans treat 
The Biblical Mythological Images of American Women in the Novel of Mice and Men

them with isolation and alienation to the extent that they can be killed normally in the name of God (High, Peter B : 1986):

"The 1960 was the time of great witchcraft panic. In the town of Salem, Massachusetts, Young girls and old women were arrested and put into trail as witches. A number of these people were put to death for selling their souls to the Devil" ${ }^{2}$

Puritanism can be contextualized in this sentence: God sends them to ultimately deliver his message through biblical texts to deliver his sacred message, universally. The very eminent aspect of teaching morality is transmitted by radicalizing and purification. Nevertheless, the role of woman has been hardly perceived in the Bible, in most cases, she has been defined exclusively as the body of sexuality. When Cotton Mather admits, while he was writing his entitled book "Magnalia Christi Americana", that the attitude of choosing women as witches had been a mistake, but it was a good way to stop them. The first puritans have been seen as the non-democratic people that lived for a long time ago in the land of America. This radicalization is a way of not behaving normally with humanity. Then, after this paradigm of brutality, there being also writers whom they have been inspired by the realm of brutality over women. That world of brutality consecutively begins with a group of writers that set up rules of puritanism and everything which is out the biblical context is seen the sinful way of live "The New England Puritans, and some other protestant groups believed that the theatre was an invention of the Devil" 3. It is granted that there had been also women writers that had not had ability to expose their writings in the realm of fiction, simply, because it was against the will of god. If someone attempts to write a particular story, she could be directly condemned as the user of the Black Magic and then nobody wants to write novels because of not getting into terribly social troubles ( High, Peter B : 1986):

"Novel had been considered a dangerous form of literature by the American Puritans. Novels put immoral ideas into the heads of young people"3

Most of the writers had been writing about themes that were totally in contrast with the women deeds like "Treachery" ,"Sexuality", "Fidelity" ....; the first puritan writer , Edward Johnson, writes The Wonder-Working Providence of Sion's Saviour in New England (1950); then, Thomas Hooker writes (1586) A Survey of the Summe of Church Discipline (1948) ; then, the emergence of John Coton's book Ways of Churches of Christ in New England (1645). Then, the family of Mather wanted to make a change in order to provide democracy rather than considering religious democracy as the only existed purely moral lessons : Richard Matter (1596) the founder of this family and he was the Puritan minister; Increase Mather (1939) writes his unforgettable book that hardly violated the history of feminism, Remarkable providences (1984). He was the eradicator of witches, as many of the old women and young women were arrested and killed, inasmuch as they were practicing Witchcraft.

Even if American literature cannot admit the unvoiced issues of religion, Modern Writers wrote about it and they consider themselves as victimized authors of historicism: John Steinbeck, is obviously influenced by religious texts and this impact is scanned in this writing systematically through logical investigations, particularly, the way he describes woman. He inspires more from the paradigm of religion, inasmuch as there are tracks of symbolic terms that makes us to consider Steinbeck as puritan writer, not as a modern writer .The commencement of brutality stopped shortly after the death of such radicalized Puritans, but the spirit of believing in witchcraft continued to be exploited in Modern literature as an archetype concept in order to produce great novels.

\section{Social and Biblical Images of Women of Steinbeck's Mental Thinking}

The incipit begins with the description of nature that is somehow the land of California, and then the author describes a simple woman as if she is culturally disoriented person and as if it is something that is only attributed to the world of pleasure. This appearance bothers mostly the readers of the Twentieth-First Century due to the unplaced position that Steinbeck creates for women through his narrative texts and in that the status of woman is badly described 
The Biblical Mythological Images of American Women in the Novel of Mice and Men

"Lennie's face broke into a delighted smile. "Why sure, George. I remember that... but... what'd we do then? I remember some girls come by ${ }^{1}$ and you says... you says..." The hell with what I say" 4

The first impression the reader gets through this citation is that Leenie belongs to an illiterate social class .His stuttering makes him the stupid person since whatever he utters like words he add "S" to every uttered sound, seeing that Steinbeck chooses deliberately this person in the light of depicting as to how this rural man thinks, because he never have had a chance to be at the school. Therefore, the educational background of this character is a tool to deconstruct how peasants reckon on women. This upon quotation detects the negative impact on women, because it [she] symbolizes here the realm of sexuality and pleasure. In fact, this is verily essential due to the fact the most of American Californians do agree upon this hellish description of women and this explains Steinbeck's writings depicted the realism of the United States, to some large extent. Another point that must be overlooked is that - how religiously Steinbeck's texts portray bastardy the essence of humanity under the name of considering woman as the corpse "And the rib, which the Lord God had taken from man, made he a a woman, and brought her unto The man".5 As the bible mentions that the creation woman is due to the existence of manhood; it says that the rib of man is taken from him so that to produce what is known today as women. According to this biblical quotation, woman is not free in terms of liberty and actions; she is extremely attached to man in everything. Illustrating this biblical sense is pivotally vital in the hope that readers can deconstruct religious meaning from Steinbeck's strategy of his narratology. This is clearly coupled as soon as Steinbeck blindly reflects myriads of symbols "Woman" and "Snake" and Jesus" in his novel that harshly over-symbolizes his narrative structure to mythologize the sense of a new sacred meaning, to be completely influential in American Literature :

"A water snake glided smoothly up the pool, twisting its periscope head from side to side; and it swam the length of the pool and came to the legs of a motionless heron that stood in the shallows. And the beak" 6

This seems somehow bizarre relation between "woman" and "snake", forasmuch as the readers will not understand the relationship between two binary oppositions that had been indeed used in the American History: the image of snake relates woman's actions as it symbolizes something vicious that would be happen sooner or later. All "Women", in the earlier period of puritanism, do not obey rules of puritanism because they were considered as "Snakes" which is the chosen name of women who never believed in the will of god. Whenever we get across with this word "Snakes", it would lead us to revive the period of Mather. At that time, women were killed and murdered because of considering them as Witches. A Snake was another adjective to categorize women as witches that choose to be out of the circle of masculinity .John Steinbeck narratologizes his text through using symbolic images as religious devices to produce the beauty of Modern Literature and this attractiveness is provided as soon as he uses Snakes as sinful images of women and this explains why he chooses to evoke the word "Snake" in the end of Mice and Men. Therefore, the author manipulates his characters to be occurred in all difficult situations and the word is a hint for the reader to be analyzed.

Steinbeck knows exactly from his own experience that women are considered something that is attributed completely to men, during that period of the international Crisis in American Society, Man suffers from the socalled "Great Depression" that globally affects the economy of the United States. Man suffers at that time from poverty and unemployment. Nonetheless, women were not even considered as human beings and most of them were put as prostitutes to work days and nights in the big houses of prostitution "Brothels" with other victims. Most of them were killed due to that fact that they refused to work as prostitutes, but, in the end, they died courageously. Regardless the negative images of prostitution, women were slaves to men. The author depicts

1. In this context, the phrasal verb describes the for shawing process of sexuality by the expression of coming by 
The Biblical Mythological Images of American Women in the Novel of Mice and Men

this mysterious reality; for example, when this woman wants to achieve her dream to be a famous actress in Hollywood. She was living in the rural mountain of California and waiting for her promised lover to come and get her into the right place [Hollywood] of her dream

"She went on with her story quickly, before she should be interrupted. "'Nother time I met a guy, an' he was in pitchers. Went out to the Riverside Dance Palace with him. He says he was gonna put me in the movies. Says I was a natural. Soon's he got back to Hollywood he was gonna write to me about it." She looked closely at Lennie to see whether she was impressing him" ${ }^{7}$

This image shows sadly how women were not fortunate to express everything they wanted to be and the dream was something that is impossible to realize without a real man. Steinbeck's is very critical to the point that he uses his symbolic reflection in his narrative writings to change things and to discuss themes that cannot be talked publically during that time of misery and sexual exploitation.Though women are now being outlined as equals to men , though feminists writers of 40's or before \{Mary Ritter Beard (1946); Woman as a Force in History : A Study in Tradition and Realities; Evelyn Reed (1954), The Matriarchal-Brotherhood: Sex and Labor in Primitive Society \}, Though Steinbeck's book The In Dubious Battle reveals the same issues of neglecting women and considering them as objects of sexuality "Prostitution", this image of inferiority was explored from American society and extracted from realistic cases of women since woman was always as the heritage slave of man as well as this harsh situation is demonstrated in the story when this woman was waiting her lover to put her into the promised position of being as an actress. In the other hand, most of women of this era are contextualized as bodies that men needed for sex and this selfish image portrays how life is difficult for them at that time because reality for them hads been something similar to their writing of fiction .In this quotation, there being positive images about women sensitivity and love that deconstructs as to thow women at the time were totally passionate, kind and open minded:

"She knelt in the hay beside him. "Listen," she said. "All the guys got a horseshoe tenement goin' on. It's on'y about four o'clock. None of them guys is goin' to leave that tenement. Why can't I talk to you? I never get to talk to nobody. I get awful lonely." 8

This model of looking at woman is sensitive and gentle, because she wants to be heard and needs lovely sex rather than brutally sex. In fact, she interacts Leenie to listen to his full story and to attract his desire at the same to arouse his sexual feeling and this is a normal quality of live before sex would begin, but it is a positive act. In the previous descriptions, women viewed as the infidels and inappropriate creatures in American society, due to the domination of religious texts in American society that eradicates their status in literature. Even if there were women that attempted to write about their sexuality and to express their emotions through literature, nonetheless it was a period of massacre and killing.

\section{CONCLUSION}

The role of women was not a clear message, inasmuch as it was the realm of an unknown reality because History always remains as something that cannot be completely said. The bible, unfortunately, contextualizes the inferiority of woman as if it is the belonging to men and they shall do no mistakes, otherwise what is known as "malediction" and "curse" would curse the whole humanity and everything would be disastrous because of this infidel woman. Steinbeck's texts are very directive, forasmuch as they explain how Californians think about women. He defends woman as the Priest in his writings as if we are reading the bible that is why the reader would see a huge biblical vocabulary which means Steinbeck reads many times the Bible and then he begins writing novels as if he is reading the bible again and again .According to his biography, Steinbeck's stopped his writing once he gets into personal troubles with his jobless routines and it was his lovely woman that takes care of him in every moment to support him with the living conditions. Despite his difficult life which is full of tragedies, his lover loved him and helped him produce the greatest novels of American Literature that won Nobel Prize. 
The Biblical Mythological Images of American Women in the Novel of Mice and Men

\section{REFERENCES}

1. High, Peter B. "An outline of American literature." (1986) P. 5-20.

2 High, Peter B. “An outline of American literature." (1986) P. 10-30.

3. High, Peter B. "An outline of American literature." (1986) P. 1-7.

4. Steinbeck, John. "Of mice and men. 1937. P1.

5. The Old Bible, Holy. "King James Version P.1-10

6. 7-8-Steinbeck, John. "Of mice and men. 1937 P 25-43

7. Benson, Jackson J. The true adventures of John Steinbeck, writer: a biography. New York: Viking Press, 1984.

8. Parini, Jay. John Steinbeck: a biography. Vintage, 1994.

Citation: Gibran Banhakeia "The Biblical Mythological Images of American Women in the Novel of Mice and Men" American Research Journal of Humanities and Social Sciences, vol 4, no. 1, 2018, pp. 1-6.

Copyright (c) 2018 Gibran Banhakeia. This is an open access article distributed under the Creative Commons Attribution License, which permits unrestricted use, distribution, and reproduction in any medium, provided the original work is properly cited. 